\title{
(Re)considering sovereignty in the European integration process
}

Yılmaz Kaplan®i

Correspondence:

yk587@alumni.york.ac.uk;

yilmaz.kaplan@erzurum.edu.tr

Erzurum Technical University, İBF,

no, 307 Erzurum, Turkey

\begin{abstract}
The World War II (WWII) as a great shock significantly weakened the European nation-state paradigm and gave the European elites a chance to achieve a 'paradigm shift' from 'the nation-state paradigm' to a 'federalist paradigm'. However, the nation-state's strong institutionalization did not allow a paradigm shift and the WWII actually created a 'paradigm duplication' in the European integration process. In this two-layered atmosphere, 'democracy' was conceptualized under the influence of 'federalist intellectual paradigm' but its implementation had to be achieved in the nation-state paradigm. Therefore, this anomaly has played a significant role in the recent stalemate the European integration process has faced. For example, the literature clearly shows the relationship between the sensitivity of European nations towards their national sovereignty and the rise of Euroscepticism in the European integration process. Moreover, the institutional and legitimate strength of the nation-state gives the nation-state paradigm a gravitational power, which gradually weakens the feasibility of the ideas originating from the federalist paradigm. As a result, this article argues that a more symbiotic institutionalization of democracy and sovereignty is necessary to make the European integration more attractive again.
\end{abstract}

Keywords: European integration, Sovereignty, Nation-state, Federalism

\section{Introduction}

The Second World War was a great shock which weakened the Westphalian political order in Europe (De Wilde, 2016, p. 153); however, it did not result in a dramatic change from the European nation-state system to a federal European system. The decline of the nation-state oriented political system in Europe due to the WWII brought about the emergence of a new group of elites (Eurocrats), who had a strong belief that the only way to establish peace in Europe would be through a federal/supranational institutionalization since, according to them, nationalism was the main reason behind the warfare in Europe. Therefore, they hoped that the WWII as a great shock would give them a chance to achieve a 'paradigm shift' from the European nation-state system to a federal one. Despite this expectation, the mentioned shock only resulted in the 'duplication of the paradigms' but not a 'paradigm shift' thanks to the nation-state's having enough institutional power to survive. Moreover, this 'paradigm duplication' resulted in an anomaly in the European integration process. Particularly, the conceptualization of democracy was done according to a federalist intellectual

(c) The Author(s). 2018 Open Access This article is distributed under the terms of the Creative Commons Attribution 4.0 International License (http://creativecommons.org/licenses/by/4.0/), which permits unrestricted use, distribution, and reproduction in any medium, provided you give appropriate credit to the original author(s) and the source, provide a link to the Creative Commons license, and indicate if changes were made. 
paradigm but its implementation happened in an intergovernmental structure. As a result, the ambition to institutionalize democracy at the EU level according to a federal logic has become one of the main reasons behind the current stalemate in the European integration process.

To empirically support this argument, the article firstly focuses on the issue of how the Second World War as a great shock created a federalist paradigm as an alternative to the nation-state system in Europe (the paradigm duplication). Subsequently, it analyses how the institutional and legitimate strength of the nation-state gives the member states a gravitational power in the European integration process which gradually weakens the feasibility of the federal project.

\section{Sovereignty versus solidarity: Two paradigms, one integration}

The Second World War as a great shock weakened the European nation-state system and gave a group of European elites the power to develop a federal European project as an alternative to the existing European nation-state system (Burgess, 2000: p. 69; 2009). For instance, the European federalists led by the influential European federalist Alberto Spinelli declared the Ventotene Manifesto (1941) defining the European nation-state system as the main reason behind the European warfare (D'Auria, 2011; Pistone, 1994). The European Union of Federalists (EUF) also pointed out the replacement of "the old system of nation states with a federation" as an efficient solution to the European warfare problem (Ifversen, 2011: p. 80). In addition to the influential intellectuals, the European leaders were also affected by federalist ideas in the wake of the WWII (Burgess, 2000). To illustrate, the-then French Foreign Minister Robert Schuman, the German Chancellor Konrad Adenauer, and the Italian Prime Minister Alcide De Gasperi supported the idea of the European integration as they witnessed the devastating effect of the European warfare and more specifically the terror of fascism in Europe (Haller, 2008). However, despite the European elites' ambition to use the WWII as a chance to achieve a shift from the nation-state system to a federal one, the European nation-states had an institutional capacity to handle this great shock. For example, "proponents of the nation-state had mustered enough strength to provide resistance to the federalist project" in The Hague Summit in 1948; therefore, the outcome was the intergovernmental Council of Europe (Wunderlich, 2007: p. 9). In addition to this, although the European federalists managed to initiate two more projects; namely, European Defence Community and European Political Community, they failed mostly because of the strong institutionalization of 'national sovereignty' in Western Europe and particularly in France (Hainsworth et al., 2004).

The strong resistance of the nation-states prevented a constitutional federal system and "the Community began life as an international organisation founded on a Treaty [the Rome Treaty] between sovereign States" (Mancini and Keeling, 1994: p. 176); therefore, the Community as a term referred to the community of member states but not European people (Caporaso, 2000, p. 16). Here, the main problem of the federalists was 'sovereignty' as the key concept legitimizing the existence of the nation state (Slanter, 1994), and they needed to develop an alternative concept to legitimize a supranational European Union. In this regard, 'solidarity' emerged as an alternative concept and Monnet had an influential functionalist idea for achieving a de facto solidarity among European nations through providing wealth to 'European people' (De 
Sousa and Moury, 2009). According to the new functionalist understanding, an economic community would initially be created, and then it would gradually evolve into a political community. Developing economic interdependence among the members would result in a spill-over effect and the economic community would be easily deepened. In the second phase of this functionalist process, interdependence and the spillover effect would start to cover political issues and this would strengthen 'solidarity' among the European people (Niemann and Schmitter, 2009).

In the light of this functionalist method, especially after the 1990s, Europeanization ${ }^{1}$ emerged as a popular concept providing a solution to the problem of how a solidarity based supranational European Union could be formed (Graziano and Vink, 2012). Particularly, many scholars argued that the Europeanization of the member states is a fact in the integration process (Bache and Jordan, 2006a, b; Börzel and Risse, 2000; Dover, 2007; Grabbe, 2006; Grigoriadis, 2009; Ladrech, 1994; Lippert et al., 2001; Mitchell, 2012). Therefore, the Europeanization process would replace solidarity with sovereignty and sovereignty as an obsolete concept would not hinder the gradually emerging supranational European political community. Under the influence of this understanding, the strength of the nation-state as the strongest political entity in the world was underestimated, and many reactions originating from the mentioned strength against the supranational institutionalization attempts were regarded as exceptional cases. For example, Britain was defined as an awkward member but the less expected the Brexit. Before the Brexit referendum, Britain was even defined as an EU member under the influence of Europeanization process (Aktipis and Oliver, 2011; Bache and Jordan, 2006a, b; Bulmer and Burch, 2009; Dover, 2007; Mitchell, 2012; Rosamond, 2003). Euroscepticism was initially viewed as a popular flame; however, it became one of the main building blocks of the European integration process in time, and taking acquiescence of the wider public is no longer guaranteed for the integrationist elites (Flood, 2002; Usherwood and Startin, 2013). In addition to Brexit and the rise of Euroscepticism, the recent irregular migration crisis has also convincingly proved that the nation-state has a strong gravitational power in the European integration process; thus, the European integration is actually reversible contrary to the supranationalist/constructivist assumption (Kaplan, 2017). Particularly, the recent irregular migration crisis is a good indicator showing that 'de-Europeanization' might be a case even for the EU's core policies when national sovereignty/interests of the member states are under threat. To illustrate, Germany, Austria, France, Denmark, and Sweden needed to take unilateral decisions to control their own national borders by suspending the Schengen Agreement as a response to the irregular migration flow in 2015 although the Schengen Agreement plays a crucial role in the institutionalization of 'solidarity' centred European Union (Baczynska, 2016; Traynor and Smith, 2016). On the other hand, even though the EU leaders promised Italy and Greece that the EU members should equally share the burden of the irregular migration in the name of 'solidarity', this promise has failed to produce meaningful results in practice due to national concerns/pressures (Ardittis, 2016; Nielsen, 2017).

As a result, it could be argued that federalist ideas created an intellectual paradigm significantly affecting the European integration process, and there has been an attempt to institutionalize democracy within the European integration process as an outcome of this federalist paradigm. Yet, it could not replace the nation-state reality in Europe because of the nation state's gravitational power originating from its strong 
institutionalization, but created a duality in the European integration process causing tension between two concepts: democracy and sovereignty. As noted above, we are also witnessing that the gravitational power of the nation-state is gradually making the federalist paradigm less effective. To show this, the following subsections focus on how the nation state's institutional and legitimate strength gives the nation-state a gravitational power diminishing the influence of the federalist paradigm in the European integration process.

\section{Nation-State's institutional strength}

The federalist paradigm mainly relies on a constructivist epistemology, which has a significant limitation in explaining/knowing the nation-state. Particularly, constructivist epistemology conceives the nation-state as an individual-like actor in a sociopsychological context but not a strong institution (Carlsnaes, 1992). In the same vein, from a Wendtian logic (see: Wendt, 1999), the nation-state as an individual is actually a product of a broader structure. Thus, according to this logic, the formation of a supranational EU emerges as an automatic outcome of the interactions between nation-states (individuals) in the broader EU structure (Johnston, 2001). According to this understanding, sovereignty is also exogenous to the nation-state because it is given to a nation-state by other states (it is not an outcome of the nation-state's historically institutionalized governance capacity and legitimacy) (Bull, 2002). Therefore, this logic assumes that the collective behaviour of the member states in the normative EU structure would develop a new kind of 'solidarity' which might substitute 'sovereignty' as a core for a polity formation. However, 'solidarity' is in practice a weak concept to substitute 'sovereignty' for several reasons.

First of all, the institutionalization of the nation-state was triggered after the Westphalian Peace (1648) by centring on sovereignty, and sovereignty as a political concept was impersonalized thanks to the high-level institutionalization of the nation state (Fabbrini, 2008). For example, the high-level of political and administrative institutionalization produced a sense of national identity in France and Britain by the eighteenth century and "the people themselves became the supreme authority, the single active principle in the state" (Laoutides, 2015: p. 16). Thus, the impersonalization of sovereignty arguably strengthened the nation-state's resistance against any great shock as the state started to represent a particular immortal nation but not any crown. Moreover, sovereignty is not only a finite concept depending on historical changes but also an infinite concept beyond the limitation of time. On the one side of the coin, it might be perceived as an ability of a nation-state to control activities within and across its borders. On the other side, it represents the legitimate authority of the nation-state over its territory. In this regard, some historical developments might affect its control capacity much more but not its legitimate authority. Therefore, a historical development might weaken a nation state's control over its borders but it still holds the legitimacy to govern. When the international atmosphere changes, it might strengthen its control capacity again. From this point of view, it might be argued that great shocks such as the WWII, the end of the Cold War or the rise of globalization could limit the European nation-states' control capacity but when the international atmosphere started to change (e.g. the decline of popularity of neoliberalism or the rise of international security concerns), the European nation-states started to strengthen their control capacities. This accounts for the reason 
why 'de-Europeanization' has easily entered the literature as an anti-thesis of 'Europeanization' (e.g. see: Ágh, 2015; Aydın-Düzgit, 2016; Raagmaa et al., 2014; Tsardanidis, 2015; Yilmaz, 2016).

Moreover, although the federalist paradigm envisages a supranational EU which perfectly melted nation states in a common European pot, Europeanization is a process involving co-existence, co-evolution, and contestation between member states' domestic systems and the EU (Dyson and Goetz, 2003: p. 13), and "it can include the transfer of policy from one European country to several other countries” (Radaelli, 2003: p. 27). Therefore, it is highly possible that contestation prevails over other options in this process if a particular member state becomes a hegemonic core for policy transfer in the EU. Especially, if one of the EU members gets 'agenda setting power', it is hardly likely that a Union with heterogeneous 28 members would achieve collective action (Olson, 2002). Thus, contrary to the constructivist assumption, the Europeanization might produce more inequality and national sentiments in the integration process. As an example proving this argument, Germany has emerged as a hegemonic power in the wake of the Eurozone crisis (Bulmer, 2014; Streeck, 2015), and this hegemonic position immediately triggered national sentiments in the Mediterranean members (Hedlund and Aline Regina Alves, 2017).

The nation-state's historical institutionalization in Europe also developed a new concept: 'nationhood' with a strong connection with sovereignty. As Anderson (2006) argued, nationhood might be historically constructed within the institutionalization process of the nation-state; however, "the nation is simply the strongest type of modern peoplehood which has claimed sovereignty over others-be it social classes, religious groups or political movements such as Oxfam" (Rozynek, 2017: p. 28). Despite this, the constructivist studies theoretically suggest an unconscious evolution of the peoplehood from the nation to the EU as a solution to dissolving the European people's strong sense of belonging to their nations (Checkel, 2005; Cram, 2012). However, the nation does not emerge as an outcome of an unconscious process but as an outcome of a deliberative interaction between authority and people (Smith, 2003). This means that a nation deliberatively obeys the sovereign power of their nation-state, and it is highly questionable how the hypothetical European identity as an outcome of an unconscious process would replace the nationhood as the strongest peoplehood. On the other hand, as noted above, the EU identity vitally needs "a sufficiently cohesive and robust we-identity" and this we-identity should contain a good sense of solidarity through which individuals also consider the needs of other members of the community while calculating their individual interests. However, this strong "we-identity" at the EU level is missing (Kielmansegg, 1996, cited in: Wolf, 2002: pp. 45-46). As a result of this fact, the EU needs a democratic institutionalization "based on non-hierarchic and consensus-seeking decision-making procedures" (Wolf, 2002: p. 48), and paying more attention to 'sovereignty' in the integration process might increase the chance of this democratic institutionalization.

Although functionalism theoretically promises a gradual change from an existing institutional structure to a new one, it does not tell us much about the future (the methods how to achieve this) (Long and Ashworth, 1999). Therefore, the implementation of this approach is highly open to the isomorphic influence of the existing institutional structure due to the cognitive limitation on alternatives (see: DiMaggio, 1983). At this point, it could be argued that the European integration as a 
functionalist process is under the isomorphic influence of the European nation-state system and this also increases the gravitational power of the nation-state in the European integration process. To illustrate, the European integration process is under the influence of the nation-state's strong bureaucratic structure. The EU Commission is mainly given as a good example to prove how an EU structure might be an influential platform for the process of Europeanization; however, national governments have the power to determine the nominees for the Commission and the commissioners were mainly selected from people with a good career in their national system (Thomson, 2011). In the same vein, Staab (2011: p. 85) also observed that "nominees rarely come from outside the governing party"; therefore, they need to consider the domestic expectations. Additionally, the Commission also witnesses a controversy over portfolio and cabinet assignments and this controversy is a good indicator that "the defence of national interests in the Commission can never be entirely removed" (Corbett et al., 2012: p. 51). As another example, the European Parliament was established to directly represent the so-called European demo at the EU level; however, the Eurosceptics, with their nationalist consideration, have been there since its foundation (e.g. the Gaullists and the British conservativists) (Leruth, 2017), and the European Parliament has become a hub of the Eurosceptics especially after the 2014 elections (Nielsen and Franklin, 2016). As a result of the isomorphic influence of the nation-state system, the institutionalization of the EU also occurs in a hierarchic way (the EU's Brusselscentred hierarchic institutionalization is similar to a nation-state's institutionalization) and this provokes a strong reaction among the European nations who do not have a 'we-identity'. For example, there are several studies showing a positive correlation between the rise of Euroscepticism and the attempts to transfer sovereign power from the member states to Brussels (Daddow, 2006; Hainsworth et al., 2004; Riishøj, 2007; Siune and Svensson, 1993; Todd, 2016; Vasilopoulou, 2009).

\section{Nation-State's legitimate strength}

The legitimacy problem due to the lack of a European demo is another important obstacle to a democratic federal institutionalization as a final outcome of the European integration process. Scharpf (2003) analytically categorizes the democratic legitimacy as input legitimacy (government by the people) and output legitimacy (government for the people), and a feedback loop is highly possible between these categories (Easton, 1957) which particularly increases the importance of the approval of people for a democratic polity. In this regard, the European integration process took place as an elitist project; the process was not governed by the people, and 'permissive consensus' of the European nations was used as a tool to substitute the missing input legitimacy in the integration process. To some extent, the permissive consensus of the European nations might provide legitimacy for the European integration. For example, "the objectives of European integration were uncontroversial in the post-Second World War period, when integration secured peace through common command over goods necessary for war" (Christiansen et al., 2004: p. 13). However, "compliance is plausible to obtain Pareto improvements where some are made better off without making anyone else worse off" (ibid.). At this point, 'permissive consensus' was also used to achieve the output legitimacy of the integration thanks to the Pareto optimality of the economic integration. However, the deepening of the EU (the ambition to create a political 
community) impairs the Pareto optimality and triggers the rise of dissensus between the European elites and the European nations (Dierckxsens, 2009, p. 200). For example, the recent financial crisis dispelled the myth that the supranational institutionalization of the EU might be achieved through establishing more independent administrative structures like the European Central Bank (the ECB) which have a capacity to take Pareto-optimum decisions relying on 'permissive consensus', because the European nations like the Greeks, Italian, and Spanish strongly expressed their disapproval of the ECB's decisions (Piattoni, 2014: p. 84). In this sense, even some of the prominent scholars, leaning on supranationalism, needed to accept that 'permissive consensus' among the European people no longer exists, and the national preferences have become more important in the European integration process (e.g., see: Fligstein et al., 2012; Hooghe and Marks, 2001; Risse, 2014).

The erosion in the Pareto optimality of the integration process has arguably increased the gravitational power of the nation-state in the integration process at the expense of the federalist paradigm. Particularly, democracy and legitimacy as twin concepts are historically institutionalized with a strong connection with national parliaments in Europe; thus, national parliaments play a crucial role in maintaining democratic norms and legitimize the polity's governance by taking ultimate accountability. However, if a solidarity oriented supranational structure diminishing the national level-decision making is developed, it is not clear who will take the ultimate accountability in the governance of the EU (Schmitter, 2000). In this regard, even the multi-level governance approach supporting a cobweb between local, national and supranational institutions in the governance of the EU suffers from the democratic accountability deficit (Papadopoulos, 2010). Therefore, as Moravcsik (2002: p. 621) argued, although the institutionalization of democracy in the European integration process is mainly problematized by the abstract federalist paradigm, national parliaments become a panacea to solve the democracy-related problems of the integration originating from the real-life difficulties. For example, Moschella (2017) highlights the importance of the national parliaments as an effective antidote to the EU's legitimacy problem after analysing the bailout negotiations in the Eurozone. On the other hand, national parliaments also deliberatively use their legitimate power to repulse federalist attempts in the European integration process. For instance, after the enforcement of the Maastricht Treaty, all of the member state parliaments organized European Affairs Committees (EACs) "to coordinate parliamentary scrutiny of European matters and to monitor the government representatives in the Council" (Raunio and Hix, 2000: p. 155). Additionally, as a result of the national parliaments' legitimate power, a declaration on the role of national parliaments in the EU was included in the Maastricht Treaty; the Treaty of Amsterdam needed to recognize national parliaments' involvement in the EU governance (Pratt, 1999: pp. 217-218); and the Treaty of Lisbon introduced an early warning mechanism (EWM) through which national parliaments may directly intervene in the EU level decision making and "raise objections to -and even play a role in blocking - EU legislation” (Cooper, 2012: p. 441).

\section{Conclusion}

As the WWII significantly weakened the European nation-state system, the European elites found a chance to develop a federalist paradigm for Europe. However, the European nation-states had a power to resist to this influential new paradigm thanks to 
their institutional capacity. As a result, the WWII as a great shock could not result in a 'paradigm shift' but 'paradigm duplication' in Europe's post-war era. However, as intergovernmentalist scholars (e.g. Hoffmann, 1966; Milward et al., 2000; Moravcsik, 1998) argue, with its strong institutional capacity, the nation-state managed to gradually re-correct its core position in the European political system. In particular, the nation-state's institutional and legitimate strength gives it a gravitational power which gradually makes the federalist paradigm less influential in the European integration process. Firstly, the nation state has historically been institutionalized around two strong concepts: sovereignty and nationhood, but the federalist paradigm does not have good alternatives to them. The federalist paradigm also follows a functionalist strategy which is actually under the isomorphic influence of the nation-state's strong institutional structure. Secondly, the EU's institutions face a lack of legitimacy although the national parliaments sufficiently provide legitimacy in the nation-state's governance. Therefore, the national parliaments also have a capacity to antidote EU's legitimacy problem, which dramatically worsened after the recent developments like the Brexit, the rise of nationalism in Europe, and the economic crisis in the Eurozone. As evidence supporting the findings of this article, the influential scholars (Bickerton et al., 2015, p. 703) also define the post-Maastricht period as a new intergovernmentalist era by challenging "theories that associate integration with transfers of competences from national capitals to supranational institutions".

As a result, this paper argues that more symbiotic institutionalization of democracy and sovereignty within the $\mathrm{EU}$ framework is required to make the European integration effective and attractive again. In this regard, supporting a differentiated framework for the European integration might be a good strategy to achieve the mentioned symbiotic institutionalization instead of a normative (federalist) framework imposing too much hegemonic power over the nation state (Walker, 1998). There have already been some developments in the European integration process supporting this argument. For example, the European Stability Mechanism was established in 2012 as an intergovernmental agency under public international law (but not under the EU law) against any future financial shock by the Eurozone members (Christova, 2011). Regarding this development, the vital point is that the Eurozone members, which might be considered as members more in favour of a federal European Union, needed to take an intergovernmental measure to solve any future financial problems. As another example, the European migration crisis (2015-2016) pushed the member states to found the European Border and Coast Guard Agency (2016), which complied with the sovereign logic implemented in the nation-state border control (Carrera and Den Hertog, 2016).

This case study also reveals some important findings which might pave the way for new discussions in the institutionalism studies. Particularly, the main institutional approaches consider 'great shocks' as the main means to trigger a change from an institutional structure/paradigm to another one (Gorges, 2001). However, this study shows that if an institutional structure (the nation state) has enough power, it might resist great shocks to survive. Therefore, a great shock results in not only a 'paradigm shift' but might also lead to 'duplication of the paradigms' in the post-shock era. Therefore, the literature needs further studies to make the conceptualization of two important phenomena: 'change' and 'continuity' (in an institutionalization process) more knowable for social scientists. 


\section{Endnotes}

${ }^{1}$ For a further discussion on this concept, see: Aspinwall and Schneider, 2001; Bache and Jordan, 2006a; Börzel and Risse, 2000; Coman and Crespy, 2014; Cowles et al., 2001; K. Featherstone, 2009; Featherstone and Radaelli, 2003; Grabbe, 2006; Graziano and Vink, 2007

\section{Abbreviation}

Brexit: The prospective withdrawal of the United Kingdom from the European Union; EACs: European Affairs Committees; ECB: European Central Bank; EU: European Union; EUF: European Union of Federalists; EWM: Early Warning Mechanism; WWII: Second World War

\section{Competing interests}

The authors declare that they have no competing interests.

\section{Publisher's Note}

Springer Nature remains neutral with regard to jurisdictional claims in published maps and institutional affiliations.

Received: 23 October 2017 Accepted: 19 December 2017

Published online: 05 January 2018

\section{References}

Ágh, Attila. 2015. De-Europeanization and de-democratization trends in ECE: From the Potemkin democracy to the elected autocracy in Hungary. Journal of Comparative Politics 8 (2): 4.

Aktipis, M., T. Oliver, and T. 2011. Europeanization and British foreign policy. In National and European foreign policies Towards Europeanization, eds, ed. R.Y. Wong and C. Hill, 72-92. Abingdon: Routledge.

Anderson, Benedict. 2006. Imagined communities: Reflections on the origin and spread of nationalism. London: Verso Books. Ardittis, S. 2016. Flexible solidarity: Rethinking the EU's refugee relocation system after Bratislava. http://blogs.lse.ac.uk europpblog/2016/09/21/rethinking-refugee-system-after-bratislava/. Accessed 1 Dec 2017.

Aspinwall, Mark, and Gerald Schneider. 2001. The rules of integration: Institutionalist approaches to the study of Europe. Manchester: Manchester University Press.

Aydın-Düzgit, Senem. 2016. De-Europeanisation through discourse: A critical discourse analysis of AKP's election speeches. South European Society and Politics 21 (1): 45-58.

Bache, I., and A. Jordan. 2006a. Europeanization and domestic change. In The Europeanization of British politics, ed. I. Bache and A. Jordan, 17-36. Basingstoke: Palgrave.

Bache, I., and A. Jordan, eds. 2006b. The Europeanization of British politics. Hampshire: Palgrave Macmillan.

Baczynska, G. 2016. EU's tusk warns Europe has two months to tackle migration crisis. Reuters. http://www.reuters.com/ article/us-europe-migrants-tusk-idUSKCNOUX220. Accessed 19 Jan 2016.

Bickerton, C.J., D. Hodson, and U. Puetter. 2015. The new intergovernmentalism: European integration in the postMaastricht era. JCMS: Journal of Common Market Studies 53 (4): 703-722.

Börzel, Tanja, and Thomas Risse. 2000. When Europe hits home: Europeanization and domestic change, European integration online papers (EloP). Vol. 4

Bull, Hedley. 2002. The anarchical society: A study of order in world politics. 3rd ed. London: Palgrave Macmillan.

Bulmer, Simon. 2014. Germany and the Eurozone crisis: Between hegemony and domestic politics. West European Politics 37 (6): 1244-1263.

Bulmer, S., and M. Burch. 2009. The Europeanisation of Whitehall: UK central government and the European Union. Manchester: Manchester University Press.

Burgess, Michael. 2000. Federalism and European Union: The building of Europe, 1950-2000. London and New York: Routledge.

Burgess, Michael. 2009. Federalism. In European integration theory, ed. A. Wiener and T. Diez, 2nd ed., 25-41. Oxford: Oxford University Press.

Caporaso, James A. 2000. Changes in the Westphalian order: Territory, public authority, and sovereignty. International Studies Review 2 (2): 1-28.

Carlsnaes, Walter. 1992. The agency-structure problem in foreign policy analysis. International Studies Quarterly 36 (3): $245-270$

Carrera, Sergio, and Leonhard Den Hertog. 2016. A European border and coast guard: What's in a name? CEPS paper in liberty and security in Europe. Available at SSRN: https://ssrn.com/abstract=2745230. Accessed 10 Oct 2017.

Checkel, Jeffrey T. 2005. International institutions and socialization in Europe: Introduction and framework. International Organization 59 (04): 801-826.

Christiansen, T., A. Føllesdal, and S. Piattoni. 2004. Informal governance in the European Union: An introduction. In Informal governance in the European Union, ed. T. Christiansen and S. Piattoni, 1-21. Cheltenham: Edward Elgar.

Christova, Alma. 2011. The European stability mechanism: Progress or missed opportunity? Baltic Journal of European Studies 1 (2): 49-58.

Coman, R., and A. Crespy. 2014. Still in search of Europeanization: From limited to structural change? In Europeanization and European integration: From incremental to structural change, ed. R. Coman, T. Kostera, and L. Tomini, 50-69. Basingstoke: Palgrave.

Cooper, lan. 2012. A 'virtual third chamber'for the European Union? National parliaments after the treaty of Lisbon. West European Politics 35 (3): 441-465

Corbett, Richard, J. Peterson, and D. Kenealy. 2012. The EU's institutions. In The European Union: How does it work? ed. Corbett Richard, J. Peterson, and D. Kenealy, 47-71. Oxford: Oxford University Press. 
Cowles, Maria Green, James A. Caporaso, and T. Risse, eds. 2001. Transforming Europe: Europeanization and domestic change. Ithaca: Cornell University Press.

Cram, Laura. 2012. Does the EU need a navel? Implicit and explicit identification with the European Union. JCMS: Journal of Common Market Studies 50 (1): 71-86.

D'Auria, M. 2011. The Ventotene manifesto: The crisis of the nation state and the political identity of Europe. In European identity and the second world war, ed. M. Spiering and M. Wintle, 141-158. Basingstoke: Palgrave Macmillan.

Daddow, Oliver J. 2006. Euroscepticism and history education in Britain. Government and Opposition 41 (1): 64-85.

De Sousa, L., and C. Moury. 2009. Introduction: Institutional choices in post-constitutional Europe - Facing challenges. In Institutional challenges in post-constitutional Europe: Governing change, ed. L. de Sousa and C. Moury, 1-14. London: Routledge.

De Wilde, P. 2016. Silecing the Eurocrats in public crisis politics. In The end of the Eurocrats' dream, ed. D. Chalmers, M. Jachtenfuchs, and C. Joerges, 146-165. Cambridge: Cambridge University Press.

Dierckxsens, S. 2009. Legitimacy in the European Union and the limits of the law. In Facing the limits of the law, ed. W. Devroe and B. Keirsbilck, 189-204. Berlin: Springer.

DiMaggio, Paul, Walter W Powell. 1983. The iron cage revisited: Collective rationality and institutional isomorphism in organizational fields. American Sociological Review 48 (2):147-160.

Dover, Robert. 2007. Europeanization of British defence policy. Aldershot and Burlington: Ashgate Publishing.

Dyson, K., and K.H. Goetz. 2003. Living with Europe: Power, constraint and contestation. In Germany, Europe, and the politics of constraint, ed. K. Dyson and K.H. Goetz, 3-36. Oxford: British Academy/Oxford University Press.

Easton, David. 1957. An approach to the analysis of political systems. World politics 9 (3): 383-400.

Fabbrini, S. 2008. Compound democracies: Why the United States and Europe are becoming similar. Oxford: Oxford University Press.

Featherstone, Kevin, and Claudio M. Radaelli. 2003. The politics of Europeanization. Oxford: Oxford University Press

Featherstone, K. 2009. Europeanization. In The Oxford handbook of British politics, ed. M. Flinders, A. Gamble, C. Hay, and M. Kenny, 838-855. Oxford: Oxford University Press.

Fligstein, Neil, Alina Polyakova, and Wayne Sandholtz. 2012. European integration, nationalism and European identity. JCMS: journal of common market studies 50 (s1): 106-122.

Flood, C. 2002. The challenge of Euroscepticism. In The European Union handbook, ed. J. Gower, 73-84. London: Fitzroy Dearborn Publishers.

Gorges, Michael J. 2001. New institutionalist explanations for institutional change: A note of caution. Politics 21 (2): $137-145$.

Grabbe, H. 2006. The EU's transformative power: Europeanization through conditionality in central and Eastern Europe. Basingstoke: Palgrave Macmillan.

Graziano, Paolo, and Maarten Vink, eds. 2007. Europeanization: New research agendas. Basingstoke: Palgrave Macmillan

Graziano, Paolo, and Maarten Vink. 2012. Europeanization: Concept, theory and methods. In The member states of the European Union, ed. S. Bulmer and C. Lequesne, 31-54. Oxford: Oxford University Press.

Grigoriadis, loannis N. 2009. Trials of Europeanization: Turkish political culture and the European Union. Basingstoke: Palgrave Macmillan.

Hainsworth, P., C. O'Brien, and P. Mitchell. 2004. Defending the nation: The politcs of Euroscepticism on the French right. In Euroscepticism: Party politics, national identity and European integration, ed. R. Harmsen and M. Spiering, 37-58. Amsterdam: Rodopi B.V.

Haller, Max. 2008. European integration as an elite process: The failure of a dream? New York: Routledge.

Hedlund, André, and Martins Aline Regina Alves. 2017. Germany and Greece in the Eurozone crisis from the viewpoint of the neo-neo debate. Brazilian Political Science Review 11 (1). https://doi.org/10.1590/1981-3821201700010004

Hoffmann, S. 1966. Obstinate or obsolete? The fate of the nation-state and the case of Western Europe. Daedalus 95 (3): 862-915.

Hooghe, Liesbet, and Gary Marks. 2001. Multi-level governance and European integration. Lanham-Maryland: Rowman and Littlefield Publishers.

Ifversen, J. 2011. Myth and history in European post- war history writing. In European identity and the second world war, ed. M. Spiering and M. Wintle, 75-91. Basingstoke: Palgrave Macmillan.

Johnston, Alastair lain. 2001. Treating international institutions as social environments. International Studies Quarterly 45 (4): 487-515.

Kaplan, Yılmaz. 2017. Enlargement as a case showing deliberative and reversible nature of the European integration. Atatürk Üniversitesi Iktisadi ve Idari Bilimler Dergisi 31 (1): 221-227.

Ladrech, Robert. 1994. Europeanization of domestic politics and institutions: The case of France. JCMS: Journal of Common Market Studies 32 (1): 69-88.

Laoutides, Costas. 2015. Self-determination and collective responsibility in the secessionist struggle. Farnham: Ashgate Publishing.

Leruth, B. 2017. Is 'Eurorealism' the new 'Euroscepticism'? Modern conservatism, the European conservatives and reformists and European integration. In Euroscepticism as a transnational and pan-European phenomenon: The emergence of a new spehere of opposition, ed. J. FitzGibbon, B. Leruth, and N. Startin, 46-62. Abingdon: Routledge.

Lippert, Barbara, Gaby Umbach, and Wolfgang Wessels. 2001. Europeanization of CEE executives: EU membership negotiations as a shaping power. Journal of European Public Policy 8 (6): 980-1012.

Long, David, and Lucian M. Ashworth. 1999. Working for peace: The functional apparoach, functionalism and beyond. In New perspectives on international functionalism, ed. Lucian M. Ashworth and David Long, 1-26. Basingstoke: Macmillan.

Mancini, G. Federico, and David T. Keeling. 1994. Democracy and the European court of justice. The Modern Law Review 57 (2): 175-190.

Milward, Alan S., George Brennan, and Federico Romero. 2000. The European rescue of the nation-state. London: Routledge.

Mitchell, Kristine. 2012. From Whitehall to Brussels: Thatcher, Delors and the Europeanization of the TUC. Labor History 53 (1): 25-50.

Moravcsik, Andrew. 1998. The choice for Europe: Social purpose and state power from Messina to Maastricht. London: UCL Press.

Moravcsik, Andrew. 2002. Reassessing legitimacy in the European Union. JCMS: journal of common market studies 40 (4): 603-624. 
Moschella, Manuela. 2017. When some are more equal than others: National Parliaments and intergovernmental bailout negotiations in the Eurozone. Government and Opposition 52 (2): 239-265.

Nielsen, Julie Hassing, Mark N Franklin, eds. 2016. Eurosceptic 2014 European Parliament Elections. Basingstoke: Palgrave Macmillan.

Nielsen, N. 2017. EU at odds on meaning of migrant 'solidarity'. https://euobserver.com/migration/137395. Accessed 4 Dec 2017.

Niemann, Arne, and Philippe C. Schmitter. 2009. In Neofunctionalism, In European integration theory, ed. Antje Wiener and Thomas Diez, 2nd ed., 25-41. Oxford: Oxford University Press.

Olson, Mancur. 2002. The logic of collective action: Public goods and the theory of groups. 20th ed. Cambridge: Harvard University Press.

Papadopoulos, Yannis. 2010. Accountability and multi-level governance: More accountability, less democracy? West European Politics 33 (5): 1030-1049.

Piattoni, S. 2014. Representation as delegation: A basis for EU democracy. In The representative turn in EU studies, ed. S. Kröger and D. Freidrich, 70-88. London: Routledge.

Pistone, S. 1994. Alberto Spinelli and the strategy for the United States of Europe. In The European Union: Readings on theory and practice of European integration, ed. B.F. Nelsen and A. Stubb, 69-76. London: Lynne Rienner.

Pratt, T. 1999. The role of national parliaments in the making of European law. In In the Cambridge yearbook of European legal studies, ed. A. Dashwood and A. Ward, 217-232. Oxford: Oxford Hart Publishing.

Raagmaa, Garri, Tarmo Kalvet, and Ragne Kasesalu. 2014. Europeanization and de-Europeanization of Estonian regional policy. European Planning Studies 22 (4): 775-795.

Radaelli, C. 2003. The Europeanization of public policy. In The politics of Europeanization, ed. K. Featherstone and C. Radaelli, 27-56. Oxford: Oxford University Press.

Raunio, Tapio, and Simon Hix. 2000. Backbenchers learn to fight back: European integration and parliamentary government. West European Politics 23 (4): 142-168.

Riishøj, Søren. 2007. Europeanization and Euroscepticism: Experiences from Poland and the Czech Republic. Nationalities Papers 35 (3): 503-535.

Risse, Thomas. 2014. No demos? Identities and public spheres in the euro crisis. JCMS: Journal of Common Market Studies 52 (6): 1207-1215.

Rosamond, B. 2003. The Europeanization of British politics. In Developments in British politics, ed. P. Dunleavy, A. Gamble, R. Heffernan, and G. Peele, 39-59. Basingstoke: Palgrave.

Rozynek, M. 2017. A philosophy of nationhood and the modern self. Basingstoke: Palgrave Macmillan.

Scharpf, Fritz W. 2003. Problem-solving effectiveness and democratic accountability in the EU. Max Planck Institute for the Study of societies. MPIfG working paper 03/1, 2003.

Schmitter, Philippe C. 2000. How to democratize the European Union-and why bother? Lanham: Rowman \& Littlefield.

Siune, Karen, and Palle Svensson. 1993. The Danes and the Maastricht treaty: The Danish EC referendum of June 1992. Electoral Studies 12 (2): 99-111.

Slanter, M. 1994. Political elites, popular indifference and community building. In The European Union: Readings on the theory and practice of European integration, eds. B. F. Nelsen and C-G. Stubb, 153-168. London: Lynne Rienner.

Smith, Rogers M. 2003. Stories of peoplehood: The politics and morals of political membership. Cambridge: Cambridge University Press.

Staab, Andreas. 2011. The European Union explained: Institutions, actors, global impact. Bloomington: Indiana University Press.

Streeck, Wolfgang. 2015. German hegemony: Unintended and unwanted. Eurozine. http://www.eurozine.com/germanhegemony-unintended-and-unwanted/. Accessed 13 Aug 2017.

Thomson, Robert. 2011. Resolving controversy in the European Union: Legislative decision-making before and after enlargement. Cambridge: Cambridge University Press.

Todd, John. 2016. The UK's relationship with Europe: Struggling over sovereignty. Basingstoke: Palgrave Macmillan.

Traynor, I., and H. Smith, H. 2016. EU border controls: Schengen scheme on the brink after Amsterdam talks. The Guardian. http://www.theguardian.com/world/2016/jan/25/refugee-crisis-schengen-area-scheme-brink-amsterdamtalks. Accessed 26 Jan 2016.

Tsardanidis, Charalambos. 2015. Greek foreign policy: The de-Europeanisatin impact of the economic crisis. Hellenic Studies/Etudes Helleniques 23: 1.

Usherwood, Simon, and Nick Startin. 2013. Euroscepticism as a persistent phenomenon. JCMS: Journal of Common Market Studies 51 (1): 1-16.

Vasilopoulou, Sofia. 2009. Varieties of euroscepticism: The case of the European extreme right. Journal of Contemporary European Research 5 (1): 3-23.

Walker, Neil. 1998. Sovereignty and differentiated integration in the European Union. European Law Journal 4 (4): 355-388.

Wendt, Alexander. 1999. Social theory of international politics. Cambridge: Cambridge University Press.

Wolf, K.D. 2002. Contextualizing normative standards for legitimate governance beyond the state. In Participatory governance: Political and societal implications, ed. J.R. Grote and B. Gbikpi, 35-50. Opladen: Springer.

Wunderlich, J.U. 2007. Regionalism, globalisation and international order: Europe and Southeast Asia. Aldershot Ashgate Publishing Company.

Yilmaz, Gözde. 2016. From Europeanization to de-Europeanization: The Europeanization process of Turkey in 1999-2014. Journal of Contemporany European Studies 24 (1): 86-100 